\title{
Prezentacje
}

\section{Sny, świadomość i jaźń: perspektywa filozoficzna}

Jennifer M. Windt

TEKSTY DRUGIE 2016, NR 5, S. 338-359

DOI: $10.18318 /$ td.2016.5.22

M niej więcej jedną trzecią życia spędzamy, śpiąc, a badania dowodzą, że znaczną część tego czasu zajmują nam sny. Jednak większość z nas rzadko pamięta swoje sny, a nawet gdy pamiętamy, mamy trudność z tym, by przypomnieć sobie więcej niż jeden na noc. Mimo tego braku naturalnej zdolności do zapamiętywania snów, dzięki relacjom zdawanym po przebudzeniu przez uczestników badań laboratoryjnych, wiemy o ich zróżnicowaniu oraz występowaniu innych procesów kognitywnych. Współczesne badania naukowe nad snem i marzeniami sennymi owocują nieprzerwanym napływem nowych empirycznych danych. Można założyć, że badania te będą miały olbrzymi wpływ na naukowe i filozoficzne teorie świadomości i jaźni. Aby jednak zrozumieć otrzymywane dane, niezbędne jest stworzenie kompleksowej struktury teoretyczno-metodologicznej, umożliwiającej opisanie świadomych doświadczeń podczas snu.

Celem mojej książki Dreaming jest zaproponowanie takiej właśnie struktury. Teraz zaś odpowiem na pytania, które uznaję za szczególnie ważne dla wzbogaconej
Artykuł złożony z tekstów Jennifer M. Windt opublikowanych na stronie The Brains Blog (philosophyofbrains.com).
Jennifer M. Windt wykłada filozofię na Monash University. W latach 2009-2015 badaczka i wykładowczyni na Uniwersytecie Jana Gutenberga w Moguncji i kierowniczka zespołu MIND Group. Autorka książki Dreaming (mitpress.mit.edu/ books/dreaming), współedytorka, wraz zThomasem Metzingerem, strony internetowej Open Mind (open-mind.net). Jej badania skupione są na filozofii umysłu i filozofii kognitywnej, w szczególności na tematyce śnienia, snu i samoświadomości. 
o badania empiryczne (miejmy nadzieję, że również pouczającej) filozoficznej teorii śnienia. Zacznę od zaprezentowania krótkiego i selektywnego przeglądu zmieniających się koncepcji snu i śnienia w badaniach naukowych i filozofii.

\section{Nowa mapa koncepcji śnienia}

Szybkość zmian w teoriach naukowych i filozoficznych poświęconych spaniu i śnieniu dorównuje ulotności pamięci o snach. Najlepiej z nich znane są: teoria snu Freuda, przedstawiająca sny jako zakamuflowane i ocenzurowane formy spełniania pragnień, oraz odkrycie fazy snu REM w latach 50., co zapoczątkowało naukowe badania nad snami i spaniem (zob. doskonały przegląd: Kroker 2007). Lecz zarówno przed, jak i po tych paradygmatycznych zwrotach teorie i koncepcje snu oraz śnienia ulegały różnym zmianom i udoskonaleniom. Podczas gdy starożytni uznawali sny za przesłania od bogów, Arystoteles w swoim traktacie $O$ snach zaproponował pierwszą naturalistyczną teorię śnienia: uważał, że senne wizje są powiązane ze szczątkową aktywnością organów zmysłowych podczas snu. Podobnie jak odbicie w wodzie, aktywność ta jest najbardziej wyraźna podczas ciszy głębokiego snu, który następnie produkuje najbardziej wyraźne wizje. Śnienie było w pewnym sensie efektem ubocznym świadomej percepcji na jawie, a spanie, po prostu, jej brakiem. Ta podstawowa idea snu i jawy jako przeciwieństw przetrwała aż do XX wieku, kiedy sen był powszechnie uznawany za jednolity okres zmniejszonej aktywności mózgu: stan, w którym jesteśmy w przeważającym stopniu wyłączeni z życia.

W latach 50. odkrycie fazy snu, która objawia się dorównującą jawie aktywnością EEG (elektroencefalografii), prawie całkowitym paraliżem mięśni i szyblimi ruchami gałek ocznych (stąd pojęcie REM - rapid eye movements, przypis tłumacza), zrewolucjonizowało naukowe koncepcje snu. Sen był teraz rozumiany jako skomplikowana struktura składająca się z różnych faz. Myślano też, że marzenia senne nie są przypisane konkretnej fazie snu, a raczej mogą występować w dowolnej jego fazie.

Zasadniczo uczestnicy badań laboratoryjnych potwierdzają występowanie snów w prawie $80 \%$ przypadków po przebudzeniu ze snu REM (sen płytki), ale znacznie rzadziej po przebudzeniu ze snu NREM (non-REM, sen głęboki - przypis tłumacza) (Nielsen 2000). To połączenie intensywnych doznań subiektywnych i wysokiej aktywności mózgu przy braku reakcji behawioralnych i zewnętrznym braku aktywności początkowo wydawało 
się paradoksalne (w istocie sen REM czasami jest nazywany „snem paradoksalnym"). Zaprzeczało to przekonaniom behawiorystów i zdawało się sugerować, że występowanie snów może zostać obiektywnie zmierzone, a nawet przewidziane na podstawie pomiarów polisomnografu uzyskanych podczas snu REM (zob. Dement \& Kleitman 1957). Odkrycie to groziło podważeniem uprzywilejowanej pozycji, jaką zajmowały subiektywne relacje snu, jedynego dotąd źródła potwierdzającego występowanie snu lub jego brak.

W rezultacie filozoficzne teorie snów i rozwijająca się gałąź empirycznych badań nad snem zaczęły ze sobą konkurować. Norman Malcoln (1956, 1959) zadeklarował, że sama próba analizowania snów naukowo, niezależnie, a może nawet przez zaprzeczenie subiektywnym relacjom snów, jest koncepcyjnym absurdem: sny występują podczas głębokiego snu, a „jeśli osoba jest w stanie jakiejkolwiek świadomości, to, co logiczne, nie jest w stanie głębokiego snu" (Malcolm 1956, 21). Inni sugerowali, że badanie snów w laboratorium to jedyne sensowne podejście do dyskursu o snach, ponieważ nasze wsteczne wrażenie snu może być głęboko złudne jako rezultat fałszywego wspomnienia wytworzonego w momencie przebudzenia (Dennet 1976). Jeśli tak, relacje snów byłyby bezużyteczne do badań nad snem. Obecnie większość badaczy odrzuca ten radykalny sceptycyzm odnośnie do relacji snów, jednak wkład relacji w badania nad snem pozostaje kontrowersyjny (by zapoznać się z moją opinią, zob. Windt 2013 i Dreaming, rozdział 1 i 4 ).

Metodologia badań nad snami niewątpliwie się rozwinęła. Istnieją ugruntowane metody oceny zawartości relacji snów. Co więcej, choć wcześniejsi badacze snów skłaniali się do stanowiska, że marzenia senne występują tylko podczas snu REM, większość współczesnych naukowców jest świadoma, że sny mogą wystąpić w dowolnej fazie śnienia. Neuroobrazowanie przedstawia inną wersję, pokazując, jak przejściom z jawy przez zasypianie do faz NREM i REM towarzyszą miejscowe zmiany modeli aktywacji mózgu. Zmiany te dokładnie pasują do fenomenologicznych cech snów. Na przykład podczas snu REM sny są intensywne wizualnie i emocjonalnie, często zawierają obrazy ruchome, co można było przewidzieć, obserwując wysoką wówczas aktywację płatów skroniowego i potylicznego oraz ruchowe i limbiczne rejony mózgu (Desseilles 2011). Być może w przyszłości takie dane mogą być używane do zbadania zawartości indywidulanych relacji snów (by zapoznać się z pierwszymi takimi badaniami, zob. Horikawa et al. 2013). Takie spostrzeżenia mogą nawet zostać wykorzystane w eksperymentalnym manipulowaniu snami 
podczas ich trwania. Na przykład Voss et al. (2014, zob. też Voss \& Hobson 2015) badali, czy stymulacja elektryczna rejonów czołowo-skroniowych mózgu, które zwykle są deaktywowane podczas snu REM, mogą wywołać świadomość śnienia, czyli świadomość tego, że się śni. Wreszcie, kontrast między śnieniem a jego brakiem podczas tej samej fazy snu może poszerzyć istniejące badania nad neuronowymi korelatami świadomości (Noreika 2009, Siclari 2014).

Rozwinęła się również teoria snu. Współcześni filozofowie umysłu powszechnie zgadzają się, że sny są doświadczeniami w tym sensie, że są fenomenologicznymi stanami, czyli że śnienie jest jak coś, i zaczęli tworzyć sprawozdania wskazujące na podobieństwa między snami i standardowymi lub odmiennymi stanami jawy. Niektórzy, na przykład, porównują sny do wirtualnych rzeczywistości, sugerując, że będące celem współczesnej technologii doświadczenie obecności i immersji w rzeczywistościach wirtualnych jest w najlepszym przypadku doświadczeniem przybliżonym do marzeń nocnych (Revonsuo 1995, 2006; Metzinger 2003).Z tej perspektywy śnienie jest multimodalną halucynacją, która dobrze naśladuje fenomenologię bycia na jawie. Inni dowodza, że śnienie powinno być porównane raczej do wyobraźni i marzeń na jawie, lub zastanawiają się nad związkami między snami i światopoglądem (McGinn 2004; Ichikawa 2009).

Wszystko to rodzi ważne pytania konceptualne i metodologiczne. Gdzie dokładnie na mapie pojęć powszechnie używanych do opisu stanów jawy można ulokować pojęcie śnienia? Jaki jest związek między śnieniem i relacją snu i jak wygląda porównanie relacji snów do innych metod używanych w badaniach nad snami? Jaką rolę odgrywa fenomenologiczna jaźń, czyli poczucie bycia lub posiadania „ja”, w różnych rodzajach snów?

W Śnieniu łączę rezultaty naukowych badań nad snem z teoretyczno-koncepcyjnymi rozważaniami z zakresu filozofii umysłu oraz nauk kognitywnych, idąc w kierunku nowej, kompleksowej struktury rozumienia i opisywania snów. Przyglądam się też teoretycznym koncepcjom snu i śnienia, historycznym i dzisiejszym, oraz sprawdzam, jaki miały wpływ na empiryczne dane (lub jak same się do nich dostosowały). Często te historyczne bezdroża przypominają o ważnych, lecz zapomnianych już pytaniach i podkreślają warunkowość współcześnie popularnych opinii. Kolejna część jest wstępem do centralnego tematu książki, którym jest stwierdzenie, że analiza samodoświadczenia w snach jest kluczowym elementem potrzebnym do stworzenia kompleksowej teorii śnienia, mogącym również wzbogacić współczesne teorie samoświadomości. 


\section{Lokalizowanie śniącego ,jja" w świecie snów}

Wszyscy śnimy każdej nocy i większość z nas jest w zasadzie pewna, że wie, jak to jest śnić. Ale jak dobrze w gruncie rzeczy znamy fenomenologię śnienia? Czy naprawdę możemy być pewni, że opisując nasze sny, nie zdajemy się po prostu na preteoretyczne założenia lub istniejące uznane teorie fenomenologii śnienia? I nawet zakładając, że bylibyśmy w stanie z powodzeniem opisywać własne sny, czy możemy generalizować na podstawie własnych doświadczeń, jak to jest mieć „typowy sen”?

Pobieżny przegląd historycznej i współczesnej literatury filozoficznej o śnieniu pokazuje, że intuicyjne i potoczne opisy śnienia doprowadziły do krańcowo odmiennej konkluzji. Tradycyjnie od dawna uznawano, że sny dokładnie naśladują fenomenologię normalnego stanu na jawie.

Taki pogląd jest wpisany w Kartezjański scenariusz sennego sceptycyzmu. W Medytacjach Kartezjusz mówi nam, że nawet jego doświadczenie siedzenia przy kominku, patrzenia na kartkę papieru, wyciągania ręki lub ruszania głową, a nawet zastanawianie się, czy śni, może (co często się zdarza) dziać się we śnie. Jak twierdzi Revonsuo (2006): „nie ma niczego w samym doświadczeniu, w faktycznym jakościowym aspekcie doświadczenia, co odróżnia to doświadczenie senne od odpowiednika na jawie” (82); „cechy doświadczeń sennych są identyczne z cechami doświadczeń na jawie" (84).

Ten pogląd może wydawać się całkowicie sprzeczny z intuicją. Od dawna sny opisuje się jako formę wyobrażania sobie czegoś lub nawet myślenia podczas snu. Sporadycznie łączy się to z twierdzeniem, że śnienie przypomina marzenie (McGinn 2004; Ichikawa 2009). Ostatecznie, przynajmniej w pewnym sensie, mamy kontrolę nad naszymi snami i ponieważ to my domyślnie jesteśmy autorami własnych snów, nie możemy, jak głosi odmienny pogląd, naprawdę odbierać postaci, obiektów i wydarzeń sennych jako rzeczywistych. Zgodnie z tym punktem widzenia snom brakuje wyrazistości - w końcu wszyscy wiemy, że uszczypnięcie się we śnie nie boli (czy na pewno?).

Z tej różnicy zdań możemy wywnioskować, że fenomenologia snów nie jest czymś, co powinno być badane zza biurka. Twierdzenia z zakresu fenomenologii snów powinny opierać się raczej na analizie wielu relacji ze snów, zebranych w warunkach kontrolowanych, np. po przebudzeniu w laboratorium, i korzystaniu ze starannie sformułowanego kwestionariusza (patrz Domhoff 2003; Kramer 2013). Istnieją też liczne metodologiczne obiekcje odnośnie do najbardziej precyzyjnych metod oceniania relacji ze snów (Sikka et al. 2014).

Ale nawet to, co mówią nam badania naukowe o snach, może się zmienić. Eric Schwitzgebel $(2002,2011)$ skrupulatnie udokumentował zmianę 
w opiniach, od początkowego twierdzenia, że głównie śnimy na kolorowo, do popularnej od lat 30. do 6o. tezy, że nasze sny są czarno-białe, którą zastąpiła znów pierwotna, popularna do dnia dzisiejszego. Schwitzgebel sugeruje, że ta obserwowalna zmiana opinii to powód do sceptycyzmu. Może wcale nie znamy fenomenologii snów tak dobrze, jak nam się wydaje.

Częściowo odpowiedzialne za te różnice mogą być szybko zmieniające się metodologie stosowane w badaniach nad snami. Jednak nawet przy udoskonaleniu metod trudno byłoby znaleźć szybki i łatwy sposób scharakteryzowania fenomenologii snów.

$\mathrm{Z}$ istnienia równoległych nurtów w myśleniu o fenomenologii snów oraz z historycznych zmian opinii możemy wywnioskować, że same marzenia senne są bardzo zróżnicowane. Przykładowo w jednym z badań, podczas którego pytano uczestników, czy śnili na kolorowo czy czarno-biało, od 10 do 20\% osób opisywało sny mieszane, czyli częściowo w skali szarej i częściowo na kolorowo (Murzyn 2008). Sny subtelnie różnią się też od doświadczeń na jawie. Gdy uczestników poproszono o porównanie zdjęć o różnym stopniu nasycenia kolorami oraz o rozmaitej jasności i klarowności do wyobrażeń snów wizualnych, to np. ocena była inna w tonicznych, a inna w fazowych momentach REM. Autorzy skonkludowali, że „najczęściej opisywaną kategorią sennych wizji była ta przypominająca rzeczywistość", dodając, że "najczęściej występującymi odchyleniami od rzeczywistego wizerunku były utrata nasycenia kolorów i utrata szczegółów tła" (Rechtschaffen \& Buchignani 1992, 150).

Te trudności zwracają naszą uwagę na fakt, że jest coś wadliwego w pierwotnym pytaniu, czy śnienie jest bardziej zbliżone fenomenologicznie do wyobrażania, czy do postrzegania. Być może próba opisania fenomenologii snów na podstawie modeli stanu czuwania (którego cechy fenomenologiczne same też są zróżnicowane i często nie do końca zrozumiałe) wprowadza nas w błąd. Być może nie powinniśmy oczekiwać, że fenomenologia snów idealnie wpasuje się w jedną lub drugą stereotypową definicję. Każde generalizujące, wszechobejmujące twierdzenie związane z fenomenologią snów może prowadzić do uproszczeń w myśleniu, które pomijają prawdziwe, ciekawe różnice fenomenologiczne między snami a kontrastującym z nimi stanem jawy (po szczegółowe rozważenie tego problemu zob. Windt \& Noreika 2011).

Szybko natkniemy się też na kontrprzykłady. Na przykład od dawna wiadomo, że sny obejmują wizualne obrazy i wrażenia ruchowe (Hobson et al. 2000; Schwartz 2000). Jednak sny bez obrazów istnieją, a wizja w snach może zostać częściowo utracona wskutek uszkodzenia płatu czołowo-skroniowego 
(zespół Charcota-Wilbrandta; Solms 1997). Dodatkowo nie wszystkie sny przedstawiają ruch; sny statyczne są czasami odnotowywane w etapach 2. i 3. snu NREM (Noreika et al. 2009).

Dlaczego więc po prostu nie założyć, że śnienie jest z natury rzeczy zjawiskiem niejednorodnym, ulegającym zróżnicowaniu. Sny każdego z nas są różnorodne, różnią się także od snów innych osób. Może najlepsze opisy snów są nieusystematyzowane: być może istnieje tylko nikłe podobieństwo różnych doświadczeń, które uznaje się za sny. Tego rodzaju hybrydyczny opis jest możliwy, ale, przynajmniej w fazie początkowej, niezbyt zachęcający.

Dla projektu redefiniowania koncepcji śnienia i określenia jej granic, a także jej relacji z koncepcjami określającymi normalne i odmienne stany na jawie (takie jak halucynacja, gra wyobraźni, percepcja, iluzja i przekonania) ważnym pytaniem jest, czy istnieje fenomenologiczny rdzeń śnienia, ta sama i niezróżnicowana fenomenologiczna cecha, która jest podstawą wszystkich snów (czyli jest do pogodzenia ze zróżnicowaniem snów), ale umożliwia też odróżnienie snów od zjawisk pokrewnych, takich jak halucynacje hipnagogiczne występujące w momencie zasypiania.

W Dreaming stawiam tezę, że to jaźń fenomenologiczna, czyli poczucie bycia lub posiadania „ja”, pozwala określić fenomenologiczny rdzeń śnienia. Liczne badania potwierdziły, że olbrzymia większość relacji snów opisuje obecność „śnionego «ja»” (np. Strauch \& Meier 1996). Istnieją ciekawe różnice między samoreprezentacją w różnych fazach snu (Occhionero et al. 2005; McNamara et al. 2007). Zmienia się ona również stopniowo w okresie dzieciństwa i dorastania, kiedy to w snach od pasywnego obserwatora „śnione «ja»" staje się aktywnym uczestnikiem (Foulkes 1999). Co ważne, nawet w ograniczonych snach, tych, w których możliwość widzenia obrazów została utracona, nadal często występuje poczucie bycia lub posiadania „ja” Dreaming, rozdział 7 i 11).

Musimy postępować ostrożnie. W charakteryzowaniu „śnionego «ja»” nie możemy założyć od początku, że jest ono fenomenologicznym duplikatem naszego „ja” na jawie, sobowtórem odznaczającym się taką samą bogatą fenomenologią bycia myślącym, fizycznym osobnikiem, jakim jesteśmy na jawie (chociaż, gdy się nad tym zastanowimy, nie jest do końca jasne, jak dobrze znamy, intuicyjnie i bez opierania się na danych empirycznych, fenomenologię obudzonego, cielesnego „ja”; zob. Schwitzgebel 2007). Z pewnością „śnione «ja»" w znaczny sposób może się różnić od naszego „ja” na jawie. „Śnione «ja»" może być młodszą (lub starszą) wersją ,ja" przebudzonego, może mieć inny zawód, innego partnera, nawet inną płeć. Można nawet śnić, że jest się 
zwierzęciem. Tego rodzaju sny rodzą ciekawe pytania odnośnie do tożsamości „śnionego «ja»” (Rose, \& Sutton 2013).

Jednocześnie odrębność między „śnionym «ja»” i innymi postaciami jest zachowana w większości snów (chociaż to rozgraniczenie może być rozmyte, np. w snach świadomych; zob. Windt et al. 2014). Sny są doświadczeniem intensywnie towarzyskim, średnio w jednym śnie występują cztery postacie poza „śnionym «ja»” (Kahn et al. 2002). Teoria społecznej symulacji snów głosi, że obfitość kontaktów towarzyskich w snach może dać początek teorii o ewolucyjnych funkcjach śnienia (Revonsuo et al. 2015). Samoidentyfikacja może być bardziej dynamiczna niż na jawie - podczas jednego snu można po kolei identyfikować się z wieloma różnymi postaciami. Jednak tylko jedna $\mathrm{z}$ nich w danym momencie jest odbierana jako „śnione «ja»”. Samoidentyfikacja jest stałą, oczywistą cechą doświadczenia życia na jawie; zwracania na to uwagi może się wydać zbyteczne. Jest to jednak fascynujące, że nawet w wysoce niesprzyjających warunkach - nawet w naszych snach, kiedy to bezpiecznie leżymy w łóżku, zatraceni w fantastycznych i często dziwacznych wirtualnych światach, zachowując się zupełnie inaczej niż na jawie, komunikując się z gronem postaci, które w końcu same są produktem naszej wyobraźni - ta podstawowa struktura doświadczeń jest zachowana.

Na razie chciałabym zasugerować, że kluczowym elementem tworzenia ujednoliconej i wyrazistej teorii snu może okazać się przeanalizowanie doznawanego przez podmiot związku między „śnionym «ja»” i światem snów, odczucie jakiejś obecności czy też pogrążenia się w marzeniu sennym. W następnej części zaproponuję rozwinięcie tej idei przez skoncentrowanie się na przykładach minimalnych form jaźni doznawanej w snach. Najbardziej elementarnym przeżyciem, które nadal można określić jako dotyczące jaźni, jest doznanie czasoprzestrzennej autolokalizacji w świecie snów. Dopóki istnieje fenomenologiczne „tu” i fenomenologiczne „teraz”, mamy poczucie jaźni - nadal znajdujemy się w centrum naszego „sennego świata”.

\section{Samoświadomość minimalna, śniące umysły i śpiące ciała}

Kiedy przechodzimy ze stanu przebudzenia w sen i przez różne jego fazy, zachodzą skoordynowane zmiany w aktywności mózgu, sposobie, w jaki przetwarzamy bodźce zewnętrzne ze środowiska, oraz w zawartości i strukturze doznań świadomych. Jednak dokładna relacja między tymi zmianami nie jest jeszcze do końca rozpoznana. Złożone, obrazowe sny częściej występują w fazie snu REM, ale bogate i zróżnicowane formy świadomej aktywności 
umysłowej pojawiają się we wszystkich fazach snu, łącznie z etapem zasypiania, i są często nie do odróżnienia od snów fazy REM (Nielsen 2000). W ostatnich badaniach wysuwa się hipotezę, że nawet w głębokim śnie bez snów, gdy zanikają wszelkie formy ukierunkowanych na obiekt myśli i obrazów, pozostaje jakaś forma fenomenologicznego doświadczania (Thompson 2014, 2015; Windt 2015). W rezultacie im więcej dowiadujemy się o różnych doświadczeniach podczas snu, tym bardziej złożone stają się analizy faz spania i ich taksonomia.

Zróżnicowanie śnienia i innych rodzajów świadomych stanów mentalnych podczas spania, jak również nasza niezdolność, przynajmniej na razie, znalezienia jasnej współzależności faz owego spania i faz marzeń sennych, skłania do podjęcia nowych istotnych problemów: gdzie dokładnie kończy się czuwanie i zaczyna sen? Gdzie leży granica między snami a formami świadomych czynności umysłowych podczas snu i zasypiania, które nie są zaliczane do snów? I czy istnieje fenomenologiczny rdzeń śnienia, ta sama i w dużym stopniu niezmienna fenomenologiczna cecha, która jest podstawą wszystkich snów? W poprzedniej części sugerowałam, że aby odpowiedzieć na to pytanie, sensowne byłoby skoncentrowanie się na konkretnej właściwości fenomenologii śnienia: na jego immersyjnej naturze, na odczuciu obecności w świecie snów. W takim razie nasuwa się pytanie, jak możemy kontynuować analizę tej właściwości. Co dokładnie znaczy odczuwać obecność w snach?

Czysto intelektualnie możemy zrozumieć poczucie obecności, rozróżniając dwa jej elementy. W kategoriach przestrzennych obecność wiąże się z fenomenologicznym $t u$, poczuciem znajdowania się w określonym punkcie rozleglejszego miejsca i w określonym odstępie od innych osób i obiektów w tym miejscu. W kategoriach czasowych obecność wiąże się z fenomenologicznym teraz i wrażeniem trwania, oczekiwaniem na przyszłość i odczuciem przeszłości, że coś właśnie się stało. Te dwa aspekty obecności, przynajmniej w teorii, mogłyby okazać się sprzeczne (Windt 2015); jednak ważniejsze jest teraz to, że spójnie możemy opisać wrażenie obecności bez odwoływania się do doświadczeń powszechnie łączonych z bogatszymi, bardziej skomplikowanymi formami jaźni fenomenologicznej, jak np. doznawania siebie jako jednostki myślącej i aktywnej fizycznie.

Czy istnieją jakieś podstawy, by sądzić, że czasoprzestrzenna samolokalizacja występuje w swej czystej, zredukowanej formie w snach? Zjawisko to nie było systematycznie badane, ale zaskakuje, że relacje o snach świadomych i nieświadomych czasami opisują wrażenie obecności mimo odczucia braku ciała czy nawet identyfikacją z punktowym miejscem w przestrzeni. 
Świat snów opiera się na fenomenologicznym tu i teraz i wydaje się to wystarczające, by później opisać to doświadczenie w relacji ze snu jak związane z „ja”. Nawet przy utracie innych wyobrażeń występujących w większości snów, takich jak obrazowanie wizualne i słuchowe, doznanie obecności lub samolokalizacji w szerszej czasoprzestrzeni może się utrzymywać. Wydaje się to zgodne z wrażeniem braku cielesności, które nazywam „fenomenologicznym odcieleśnieniem" (Dreaming, rozdział 7). Do wrażenia obecności lub usytuowania w świece snów wystarczy sama czasoprzestrzenna samolokalizacja. Natomiast gdy wrażenie obecności zanika, ginie granica między „ja” śnionym a światem snów; ujmując to metaforycznie, samo marzenie senne się rozpływa. Doświadczenie fenomenologiczne może się utrzymywać, ale nie powinno być zaliczane do snów w jakimkolwiek istotnym sensie tego słowa (szczegóły i przykłady, zob. Windt 2010; Dreaming, rozdział 7 i 11).

Badanie takich przypadków fenomenologicznie odcieleśnionej jaźni byłoby niezwykle interesujące $\mathrm{z}$ wielu powodów. Teoretycznie, fenomenologia czasoprzestrzennej samolokalizacji może okazać się punktem przejścia między stanami odbieranymi (i opisywanymi) jako bezosobowe a bogatszymi formami fenomenologicznej jaźni. Można ją uznać za fenomenologicznie minimalną jaźń, czyli najprostszą, najbardziej zredukowaną formę odczuwania siebie jako „ja”. Ta propozycja rozszerza istniejące badania nad pełną iluzją i OBE (doświadczeniem bycia poza ciałem - przypis tłumaczki) (Lenggenhager et al. 2007; Blanke \& Metzinger 2009; Metzinger 2013¹), wskazując, że zintegrowany, interdyscyplinarny program badawczy nad snami i iluzją całkowitą może stać się obiecującym projektem na przyszłość. Badanie fenomenologiczne minimalnej jaźni w snach, ale też bardziej skomplikowanych form samodoświadczenia obejmujących wrażenie bycia istotą cielesną, może też pomóc w wyjaśnieniu konkretnego wariantu problemu ciało-i-umysł: nazywam to „problemem ciało-mózg-ciało", czyli zagadnieniem, jak cielesne doświadczenia w snach oraz na jawie można rozumieć jako powstające ze zmiennych, przypadkowych interakcji między mózgiem i resztą ciała (Dreaming, rozdział 8).

Sny pozwalają interesująco badać tę relację, ponieważ podczas snu, a szczególnie podczas snu REM, przetwarzanie zewnętrznych i obwodowych bodźców jest znacznie ograniczone. Często prowadziło to do twierdzeń, że świadome doświadczenia w snach są całkowicie odseparowane od śpiącego ciała. Niektórzy opisują śnienie jako naturalnie występujące, przejściowe

1 Pierwotny układ zob. https://www.youtube.com/watch?v=4PQAc_Z2OfQ (8.07.2015). 
zjawisko „mózgu w pojemniku czaszki”: fenomenologicznie cieszymy się równie bogatym doświadczeniem jak na jawie, ale podczas snu to doświadczenie opiera się wyłącznie na wewnętrznej aktywności mózgu i rozwija się niezależnie od jakichkolwiek sygnałów wysyłanych przez fizyczne ciało śpiące w łóżku.

Pogląd, który rozwijam w Dreaming, analizuje tę kwestię z trochę innej perspektywy. Na początek krytycznie oszacowujemy empiryczne dane fizycznych doświadczeń w snach. Trzeba tu odnotować, że chociaż ruch jest często spotykany w snach, wrażenie dotyku, bólu, ucisku,jak również odczucia trzewne, propriocepcja i uczucie łaskotania są bardzo rzadko opisywane w relacjach ze snów (np. Hobson 1988; Schwartz 2000). Ten ogólny schemat pasuje do snów opisywanych przez niektóre grupy uczestników badań. $\mathrm{Na}$ przykład pacjenci z fantomowymi kończynami czasami śnią, że ich brakująca kończyna jest obecna, lecz w sposób ciekawie odmienny niż na jawie. W snach brakującą kończynę można widzieć i nią ruszać, ale nie czuje się jej: niemiłe uczucie mrowienia i ból, często odczuwane na jawie przez osoby po amputacji, znikają (Brugger 2008; Frank \& Lorenzoni 1989; Alessandria et al. 2011). Nie znaczy to, że nigdy nie mamy takich odczuć w snach. Wydaje się jednak, że w większości snów jaźń jest fenomenologicznie ucieleśniona tylko w małym stopniu.

Jak to się wiąże z problemem „ciało-mózg-ciało”? Jednym z powodów braku fizycznych doświadczeń zarówno w relacjach ze snów, jak i w samych snach - jeśli potraktujemy te relacje poważnie, jak moim zdaniem powinniśmy (patrz Windt 2013, Śnienie rozdział 1, 4 i 7) - może być to, że są to dokładnie typy doznań, których mózg nie produkuje pozostawiony sam sobie i w znacznym stopniu odcięty, jak podczas fazy snu REM, od śpiącego, fizycznego ciała. Fenomenologia doświadczenia jaźni w snach wiąże się z faktem, że w fazie snu REM przetwarzanie środowiskowych i obwodowych bodźców jest znacznie ograniczone. Wrażenie braku ciała, jak w fenomenologicznym odcieleśnieniu, może być tego ekstremalnym przypadkiem: w snach minimalnych fenomenologiczna jaźń opierająca się tylko na czasoprzestrzennej samolokalizacji odzwierciedla funkcjonalne, związane z fazą snu REM, odłączenie się od śpiącego ciała.

Jeżeli jesteśmy na właściwym tropie, to twierdzenie, że sny są całkowicie niezależne od uśpionego ciała, może nie być do końca trafne. W XIX wieku panowało przekonanie całkowicie przeciwne popularnym obecnie poglądom na „mózg w pojemniku czaszki” - Leibreiztheorie, czyli przekonanie, że sny są iluzjami powstającymi na wskutek zniekształconej percepcji śpiącego 
ciała. Z pewnością uproszczeniem byłoby twierdzić, że wszystkie sny mają źródło w somatycznej stymulacji. Proponuję tylko, by oprócz badania neuronowych korelatów śnienia uwzględniać również śpiące ciało w celu wyjaśnienia niektórych rodzajów doznań fizycznych (lub ich braku) w snach. $\mathrm{Na}$ przykład większość ludzi miała sen o niemożliwej ucieczce przed kimś nas ścigającym. W takich snach niemożność ruchu może być odzwierciedleniem stanu fizycznego ciała, śpiącego bez ruchu w łóżku. Podobnie proces tracenia kontaktu z fizycznym ciałem może odzwierciedlać się, na poziomie fenomenologicznym, jako uczucie nieważkości i zachwiań równowagi, które występują w snach o lataniu, pływaniu lub spadaniu (Schönhammer 2004, 2005).

Można na tej podstawie przewidywać, że eksperymentalna stymulacja śpiącego ciała będzie miała wpływ na sny, a w szczególności na „ja” śnione. I rzeczywiście: dużo częściej wpływ na sny miała stymulacja ciała, a nie stymulacja wizualna lub dźwiękowa. Na przykład pompowanie rękawa ciśnieniomierza podczas snu w fazie REM często jest inkorporowane w samo marzenie senne (Sauvageau et al. 1998; Nielsen 1993). Po stymulacji uczestnicy badań opisywali sny, w których nosili dziwne, niewygodne buty, których nie mogli zdjąć, mieli problemy z poruszaniem się, a nawet byli świadkami konia następującego na nogę innej postaci we śnie.

Jednak moim ulubionym przykładem są hipnagogiczne halucynacje, doświadczane przy zasypianiu lub podczas przebudzenia. Istnieje długa lista mitów i legend, z różnych kultur i różnych epok, opisujących nocnych intruzów, którzy wchodzą przez okno i atakują osoby śpiące w łóżku (Adler 2011). Opisy tych nocnych ataków są zawsze bardzo podobne. Często pojawiają się relacje, że dana osoba się obudziła, ale nie może wykonać żadnego ruchu i odkrywa wiedźmę-staruchę lub demona siedzących na piersiach, dławiących lub duszących. Konstrukcja tych doświadczeń - paraliż, trudności z oddychaniem i wrażenie ucisku na klatce piersiowej, jak również halucynacje wizualne - odpowiadają utracie kontroli mięśniowej i płytkiemu, szybkiemu oddychaniu, które cechuje fazę snu REM. Jeśli te cechy szczególne fazy snu REM utrzymają się po przebudzeniu, w połączeniu ze strachem, to mamy wyjaśnienie stereotypowej natury „nocnych ataków” (Cheyne 2003; Cheyne \& Girard 2007). Sporadycznie wrażenie przebudzenia podczas takich epizodów może być złudne: część osób opisujących senny paraliż mogło doświadczyć fałszywych przebudzeń, czyli realistycznych snów o przebudzeniu, ale bez możliwości poruszania się (Powell \& Nielsen 1998; Śnienie, rozdział 10).

Tak czy inaczej, jest to ciekawy przykład na to, jak podczas przechodzenia snu w jawę lub podczas snu fizyczne doznania mogą być opisane jako 
zniekształcone spostrzeganie śpiącego ciała. Badanie odczuć cielesnych w snach, jak również doznawanie braku ciała podczas fenomenologicznego odcieleśnienia może okazać się wartościowym sposobem poszerzenia badań nad całkowitymi i częściowymi iluzjami (jak iluzja gumowej ręki; patrz Botvinick \& Cohen 1998), ale też krokiem w kierunku stworzenia ogólnej teorii relacji między odczuciami fizycznymi, mózgiem i samym ciałem - i jak ta relacja zmienia się podczas przechodzenia snu w jawę.

\section{Sny oszukańcze, zaburzenia poznawcze i wgląd podczas}

Poprzednia część koncentrowała się na związkach między minimalną jaźnią fenomenologiczną w snach, czasoprzestrzenną samolokalizacją i doznaniami cielesnymi. Istnieje jednak inny, bardziej tradycyjny sposób myślenia o relacji między śnieniem i jaźnią. Polega on na kierowaniu uwagi na relację epistemiczną, jaka zachodzi między jaźnią, zarówno we śnie, jak i na jawie, i światem snów.

Z jednej strony od dawna uznawano sny i ich interpretacje za źródło prawdziwego wglądu - czy to w przyszłość, jak w jasnowidzących snach starożytnych, czy w stany ciała fizycznego, jak w snach diagnostycznych, wskazujących na chorobę, czy też w psychologiczny stan śniącego, jak w psychoanalitycznej teorii snów. Te odmienne podejścia do znaczenia snów dość często wiązały się też z odmiennymi koncepcjami ich źródeł (Windt 2015b). Od wieków myślano, że sny umożliwiają dostęp do rodzajów wiedzy niedostępnych na jawie, do wyjątkowych źródeł kreatywności i rozwiązywania problemów, a także, sporadycznie, do dawno utraconych wspomnień. Taki pogląd jest prawdopodobnie podstawą utrzymującego się nadal powszechnego zainteresowania snami i ich znaczeniem (zob. niedawną dyskusję i empiryczne badania związku między snami, ich interpretacją oraz owym wglądem; Edwards et al. 2013).

$\mathrm{Z}$ drugiej strony sny często były też uznawane za przeszkodę na drodze do wiedzy i racjonalnego myślenia. Opisywano je jako źródło przesądów, pokrewne szaleństwu i przywidzeniom na jawie (zob. niedawną dyskusję poświęconą odczuciu czegoś dobrze znanego w snach i w przywidzeniach na jawie, patrz Gerrans 2013). Najbardziej znanym filozoficznym przykładem takiego podejścia jest sceptyczny argument Kartezjusza wywiedziony ze snu w Medytacjach. Mówi on tam, że jeśli nie możemy wykluczyć, że śnimy, nie możemy ufać żadnym naszym sensorycznym odczuciom odnośnie do świata wokół nas. 
We współczesnych badaniach nad snami oraz empirycznie ugruntowanych pracach filozoficznych sny są często opisywane jako stan zaniku możliwości kognitywnych (Hobson et al. 2000; Metzinger 2003).Z tego punktu widzenia nasza niezdolność uświadomienia sobie podczas snu, że śnimy, wynika z braku racjonalnego myślenia. Nasz sposób myślenia w snach o mających w nim miejsce wydarzeniach i sytuacjach ma nielogiczny, skojarzeniowy i doraźny charakter. $Z$ tego powodu sugerowano nawet, że sny mogą być modelem w badaniach nad stanami psychotycznymi (Hobson 1999; Gottesmann 2006, 2007; zob. krytyczną analizę Windt \& Noreika 2011). Myślą przewodnią tych badań jest przekonanie, że w snach nieświadomych „ja” śnione nie może być opisywane jako jednostka aktywna poznawczo. Tylko w snach świadomych, kiedy stajemy się świadomi tego, że śnimy, możliwości poznawcze wracają do poziomu jak na jawie.

Badanie świadomych snów, czyli snów, w których śniący zdaje sobie sprawę z tego, że śni i ma nad snem pewien stopień kontroli, stało się ostatnio odrębną i ścisłą dziedziną naukową. Pogląd, że sny zawsze muszą być zwodnicze ze względu na swoją naturę i że nagłe uświadomienie sobie tego, że się śni, prowadzi do obudzenia (zob. np. rozważania Sartre’a z 1940 r. o śnieniu), okazał się nieprawdziwy. Pod koniec lat 70. dwie niezależne od siebie grupy naukowców wykorzystały pomysłowe doświadczenie (Hearne 1978; LeBerge 1985, 1988). Zakładając korelację między kierunkiem patrzenia we śnie i ruchami gałek ocznych (tzw. hipoteza skanowania), naukowcy poprosili doświadczonych w świadomych snach uczestników badań, by zasygnalizowali moment świadomości w śnie patrzeniem „prawo-lewo-prawo-lewo”. Te uzgodnione ruchy oczu były odnotowane przez elektrookulograf, a późniejsze sprawozdania potwierdzały, że śniący był w tym momencie świadomy. W ten sposób można było udowodnić, że sny świadome to zjawisko realne i że istotnie występują podczas snu. Ten wzorzec sygnalizowania potwierdzającego sny świadome został wykorzystany w wielu interesujących badaniach, np. do obserwowania zmian aktywności mózgu powiązanych z osiągnięciem świadomości we śnie (Voss et al. 2011), jak też konkretnymi gestami (jak np. zaciskanie pięści, poprzedzone i zakończone uzgodnionym sygnałem ruchu oczu; Dresler et al. 2011), czy też do porównywania, ile czasu zajmują określone czynności we śnie w porównaniu z ich odpowiednikami na jawie (Erlacher et al. 2013; patrz zamieszczona pod spodem ilustracja). Naukowcy zaczęli nawet używać stymulacji elektrycznej czołowo-skroniowego płatu mózgu w celu wywołania samoświadomości w snach (Voss et al. 2014; zob. świetny przegląd Voss \& Hobson 2015). 
Są to ciekawe osiągnięcia, rozpracowujące związek między kognitywnymi procesami leżącymi u podstaw marzeń sennych a świadomie przeżytą myślą. Wskazują też, że w snach jaźń fenomenologiczna przejawia się w różnym stopniu. Momentowi osiągnięcia świadomości we śnie towarzyszy zmiana w samopostrzeganiu. Gdy zaczynamy myśleć o toczących się w nas procesach, osiągamy metapoznawczy wgląd w naturę naszego trwającego w tym momencie stanu 'przytomności', i świadomość we śnie (Windt \& Metzinger 2007). Co ważne, w snach świadomych metapoznawcza świadomość nie przerywa trwającego snu, a co więcej, utrzymuje się równolegle do wyrazistych, a często i szalonych wyobrażeń. To kolejny powód, by twierdzić, że sposób, w jaki czujemy się obecni w snach, nie może być uproszczony do kognitywnej immersji, przypominającej sposób, w jaki tymczasowo „zawieszamy niedowierzanie", zatracając się w ciekawym filmie lub książce (zob. Dreaming, rozdział 6 i 11). Wracamy tu do wcześniej omawianej kwestii, do poczucia jakiejś obecności w snach oraz jej związku z czasoprzestrzenną samolokalizacją. Nawet sny świadome są doświadczane jako rozgrywające się tu i teraz, mimo że osoby śpiące zdają sobie sprawę z tego, że w rzeczywistości leżą w łóżku i śpią.

Można by wywnioskować, że fenomenologia myślenia i działań kognitywnych w snach jest porównywalna do włącznika światła. Powodem, dla którego zazwyczaj nie zdajemy sobie sprawy z tego, że śnimy, jest po prostu to, że o tym nie myślimy - właściwie nie myślimy wtedy o niczym. Gdybyśmy zaczęli, nasz sen stałby się świadomy. Ryzyko, na jakie naraża nas złudność snów traci w efekcie znaczenie: sny są w istocie złudne, ale tylko przez nasz brak krytycznej ich analizy i braku dystansu do nich podczas ich trwania. Sama próba krytycznego myślenia podczas snów umożliwiłaby nam, wbrew temu, co twierdził Kartezjusz, odróżnienie snu od jawy.

Uważam jednak, że pogląd ten jest tylko częściowo poprawny. Za najciekawsze uważam przypadki tzw. snów przedświadomych. W snach przedświadomych śniący zastanawia się nad tym, czy śni, ostatecznie dochodząc do mylnego wniosku, że wcale nie śpi albo nie potrafi określić swojego stanu. Jednak obiektywnie rzecz rozpatrując, ich sposób rozumowania absolutnie nie jest racjonalny. Na przykład śniący mogą dojść do wniosku, że nie śnią, ponieważ stoją na podium i w samej bieliźnie wygłaszają przemówienie, lub skonkludować, że skoro potrafią latać lub unosić się nad ziemią, to nie może być sen. Wewnętrznie są przekonani, że rozumują całkowicie racjonalnie, jednak jest to głęboko mylne (rozwijam ten motyw i opisuję empiryczne przypadki w Dreaming, rozdział 9 i 10). 
Sytuacja staje się jeszcze bardziej problematyczna, gdy weźmiemy pod uwagę tzw. zaniki świadomości. Nawet po uzyskaniu świadomości podczas snu śniącemu może wydawać się, że dosłownie dzieli sen z innymi osobami ze snu, boi się wykonywać 'niebezpieczne’ czynności (jak np. skok z urwiska), lub może zakładać, że mają one konsekwencje w świecie rzeczywistym. $\mathrm{Na}$ przykład śniący mogą próbować zanotować szczegóły snów, nadal śpiąc, by nie zapomnieć ich po przebudzeniu (patrz Dreaming, rozdział 9 i 10; dyskusja i odwołania do stosownej literatury). Oczywiście można by powiedzieć, że takie sny nie są do końca świadome. Bagatelizuje to jednak istnienie kontinuum świadomej myśli i działań kognitywnych między nieświadomymi i świadomymi snami oraz stopniowość przechodzenia z jednego w drugi (zob. próby pomiaru tej stopniowości: Voss et al. 2013). Wynika z tego, że badanie snów świadomych i nieświadomych wymaga bardziej przemyślanego podejścia. Myślenie w snach nie przypomina włącznika światła, które nagle rozświetla pokój, a raczej zabawę włącznikiem i zapominanie o nim lub uruchomienie go bez uświadomienia sobie, że światło się nie włączyło. Zazwyczaj myślenie w snach wiąże się z poznaniem częściowym lub pozornym bardziej niż rzeczywistym.

W Dreaming argumentuję, że podstawowym problemem nie jest to, że śniąc nie myślimy, ale raczej, że nasze myślenie w snach jest często wypaczone. W snach możemy mieć poczucie racjonalnego myślenia lub przypominania sobie faktów z życia, i całkowicie się mylić - fenomenologia myślenia i poznania w snach jest niewiarygodna i często wręcz złudna. Świadome sny pokazują, że racjonalne myślenie i rzeczywisty wgląd są w snach możliwe, ale sny przed-świadome (jak i zaniki świadomości w snach świadomych) dowodzą, że są one nierozpoznawalne.

Warto zauważyć, że nadaje to inne znaczenie pojęciu 'złudności' w odniesieniu do snów. Podczas gdy w kartezjańskiej wersji złudność snów dotyczyła postrzegania świata i naszego cielesnego istnienia, przykłady kognitywnego wypaczenia sugerują, że w snach mylimy się co do własnych zdolności poznawczych, naszej pozycji w tym momencie za racjonalnie myślącej jednostki (obszerniejsza dyskusja z życia wziętych przykładów złudności snów, zob. Dreaming, rozdział 10). Co więcej nawet wgląd rzeczywisty, jak w przypadku snów świadomych, może towarzyszyć myśleniu nieracjonalnemu. Można nawet powiedzieć, że dwa różne podejścia między „ja” śnionym a światem snów, opisane przez mnie na początku tej części artykułu, wcale aż tak się od siebie nie różnią. Natomiast w wielu snach zdają się uzupełniać. 


\section{Bibliografia}

Adler, S.R. (2011). Sleep paralysis: Night-Mares, Nocebos, and the Mind-Body Connection: Studies in Medical Anthropology. New Brunswick, NJ: Rutgers University Press.

Alessandria, M., Vetrugno, R., Cortelli, P. \& Montagna, P. (2011). Normal body scheme and absent phantom limb experience in amputees while dreaming. .Consciousness and Cognition", 20 (4), 1831-1834.

Blanke, O. \& Metzinger, T. (2009). Full-body illusions and minimal phenomenal selfhood. „Trends in Cognitive Sciences”, 13 (1), 7-13.

Botvinick, M. \& Cohen, J. (1998). Rubber hand “feel” touch that eyes see. „Nature”, 391 (6669), 756. doi:10.1038/35784

Brugger, P. (2008). The phantom limb in dreams. „Consciousness and Cognition”, 17 (4), 1272-1278. doi:10.1016/j.concog.2008.01.005.

Cheyne, J.A. (2003). Sleep paralysis and the structure of waking-nightmare hallucinations. „Dreaming”, 13, 163-179.

Cheyne, J.A. \& Girard, T.A. (2007). Paranoid Delusions and Threatening Hallucinations: A Prospective Study of Sleep Paralysis Experiences. „Consciousness and Cognition", 16 (4), 959-974. doi:10.1016/j.concog.2007.01.002.

Dement, W.C. \& Kleitman, N. (1957). The Relation of Eye Movements During Sleep to Dream Activity: An Objective Method for the Study of Dreaming. "Journal of Experimental Psychology", 53, 89-97.

Dennett, D.C. (1976). Are dreams experiences? „Philosophical Review”, 85 (2), 151-171.

Desseilles, M., Dang-Vu, T.T., Sterpenich, V. \& Schwartz, S. (2011). Cognitive and Emotional Processes During Dreaming: A Neuroimaging View. „Consciousness and Cognition", 20 (4), 998-1008.

Domhoff, G.W. (2003). The Scientific Study of Dreams: Neural Networks, Cognitive Development, and Content Analysis. Washington, DC, US: American Psychological Association.

Dresler, M., Koch, S., Wehrle, R., Spoormaker, V.I., Holsboer, F., Steiger, A., et al. (2011). Dreamed Movement Elicits Activation in the Sensorimotor Cortex. „Current Biology", 21 (21), 1833-1837.

Edwards, C.L., Ruby, P.M., Malinowski, J.E., Bennett, P.D. \& Blagrove, M.T. (2013). Dreaming and Insight. „Frontiers in Psychology”, 4, 979. doi:10.3389/ fpsyg.2013.00979.

Erlacher, D., Schädlich, M., Stumbrys, T. \& Schredl, M. (2014). Time for Actions in Lucid Dreams: Effects of Task Modality, Length, and Complexity. .Frontiers in Psychology", 4, 1013. doi:10.3389/fpsyg.2013.01013. 
Foulkes, D. (1999). Children's Dreaming and the Development of Consciousness. Cambridge, MA: Harvard University Press.

Frank, B. \& Lorenzoni, E. (1989). Experiences of Phantom Limb Sensations in Dreams. „Psychopathology”, 22, 182-187.

Gerrans, P. (2014). Pathologies of Hyperfamiliarity in Dreams, Delusions, and Deja Vu. „Frontiers in Psychology”, 5, 97. doi:10.3389/fpsyg.2014.00097.

Gottesmann, C. (2006). The Dreaming Sleep Stage: A New Neurobiological Model of Schizophrenia? „Neuroscience”, 140, 1105-1115.

Gottesmann, C. (2007). A Neurobiological History of Dreaming. In D. Barrett \& P. McNamara (Eds.), The New Science of Dreaming: Vol. 1. Biological aspects (pp. 1-51). Westport: Praeger Perspectives.

Hearne, K. (1978). Lucid Dreams: An Electro-Physiological and Psychological Study. Unpublished doctoral thesis, University of Liverpool, England.

Hobson, J.A. (1988). The Dreaming Brain. Basic Books.

Hobson, J.A. (1999). Dreaming as Delirium: How the Brain Goes out of Its Mind. Cambridge, MA: MIT Press.

Hobson, J.A., Pace-Schott, E. F. \& Stickgold, R. (2000). Dreaming and the Brain: Toward a Cognitive Neuroscience of Conscious States. „Behavioral and Brain Sciences”, $23,793-842$.

Horikawa, T., Tamaki, M., Miyawaki, Y. \& Kamitani, Y. (2013). Neural Decoding of Visual Imagery During Sleep. „Science”, 340 (6132), 639-642. doi:10.1126/ science.1234330.

Ichikawa, J. (2009). Dreaming and Imagination. „Mind and Language”, 24 (1), 103-121.

Kahn, D., Pace-Schott, E.F. \& Hobson, J.A. (2002). Emotion and Cognition: Feeling and Character Identification in Dreaming. „Consciousness and Cognition”, 11, 34-50.

Kramer, M. (2013). The Dream Experience: A Systematic Exploration. Routledge.

Kroker, K. (2007). The Sleep of Others and the Transformations of Sleep Research. Toronto: University of Toronto Press.

LaBerge, S. (1985). Lucid Dreaming: The Power of Being Awake and Aware in Your Dreams. New York: Ballantine.

LaBerge, S. (1988). The Psychophysiology of Lucid Dreaming. In J. Gackenbach \& S. LaBerge (Eds.), Conscious Mind, Sleeping Brain: Perspectives on Lucid Dreaming (pp. 135-153). New York: Plenum Press.

Lenggenhager, B., Tadi, T., Metzinger, T. \& Blanke, O. (2007). Video ergo sum: Manipulating Bodily Self-Consciousness. „Science”, 317 (5841), 1096-1099. doi:10.1126/science.1143439.

Malcolm, N. (1956). Dreaming and Skepticism. „Philosophical Review”, 65 (1), 14-37. 
Malcolm, N. (1959). Dreaming. London: Routledge \& Kegan Paul.

McGinn, C. (2004). Mindsight: Image, Dream, Meaning. Cambridge, MA: Harvard University Press.

McNamara, P., McLaren, D. \& Durso, K. (2007). Representation of the Self in REM and NREM Dreams. „Dreaming”, 17 (2), 113-126. doi:10.1037/1053-0797.17.2.113.

Metzinger, T. (2003). Being No One: The Self-Model Theory of Subjectivity. Cambridge, MA: MIT Press.

Metzinger, T.K. (2013). Why Are Dreams Interesting for Philosophers? The Example of Minimal Phenomenal Selfhood, Plus an Agenda for Future Research1. „Frontiers in Consciousness Research", 4, 746. http://doi.org/10.3389/fpsyg.2013.00746

Murzyn, E. (2008). Do We Only Dream in Colour? A Comparison of Reported Dream Colour in Younger and Older Adults with Different Experiences of Black and White Media. „Consciousness and Cognition”, 17, 1228-1237.

Nielsen, T.A. (1993). Changes in Kinesthetic Content of Dreams Following Somatosensory Stimulation of Leg During REM Sleep. „Dreaming”, 3, 99-113.

Nielsen, T.A. (2000). A Review of Mentation in REM and NREM Sleep: "covert" REM Sleep as a Possible Reconciliation of Two Opposing Models. „The Behavioral and Brain Sciences", 23 (6), 851-866; discussion 904-1121.

Noreika, V., Valli, K., Lahtela, H. \& Revonsuo, A. (2009). Early-Night Serial Awakenings as a New Paradigm for Studies on NREM Dreaming. „International Journal of Psychophysiology", 74 (1), 14-18.

Occhionero, M., Cicogna, P., Natale, V., Esposito, M.J. \& Bosinelli, M. (2005). Representation of Self in SWS and REM Dreams. „Sleep and Hypnosis”, 7 (2), 77-83.

Powell, R.A. \& Nielsen, T.A. (1998). Was Anna O's Black Snake Hallucination a Sleep Paralysis Nightmare? Dreams, memories, and trauma. "Psychiatry and Clinical Neurosciences", 61, 239-248.

Rechtschaffen, A. \& Buchignani, C. (1992). The Visual Appearance of Dreams. In J.S. Antrobus \& M. Bertini (Eds.), The Neuropsychology of Sleep and Dreaming (pp. 143-156). Hillsdale, NJ: Erlbaum.

Revonsuo, A. (1995). Consciousness, Dreams, and Virtual Realities. „Philosophical Psychology", 8, 35-58.

Revonsuo, A. (2006). Inner Presence: Consciousness as a Biological Phenomenon. Cambridge, MA: MIT Press.

Revonsuo, A., Tuominen, J. \& Valli, K. (2015). The Avatars in the Machine. In T.K. Metzinger \& J. M. Windt (Eds.), Open MIND. Frankfurt am Main: MIND Group. 
Rosen, M. \& Sutton, J. (2013). Self-Representation and Perspectives in Dreams: Perspectives in Dreams. „Philosophy Compass”, 8 (11), 1041-1053. http://doi.org/10.1111/ phc3.12082.

Sartre, J.-P. (1940). L'imaginaire: Psychologie phénoménologique de l'imagination. Paris: Gallimard.

Sauvageau, A., Nielsen, T.A. \& Montplaisir, J. (1998). Effects of Somatosensory Stimulation on Dream Content in Gymnasts and Control Participants: Evidence of Vestibulomotor Adaptation in REM Sleep. „Dreaming”, 8, 125-134.

Schönhammer, R. (2004). Fliegen, Fallen, Flüchten: Psychologie intensiver Träume. Tübingen: Deutsche Gesellschaft für Verhaltenstherapie.

Schönhammer, R. (2005). “Typical Dreams”: Reflections of Arousal. „Journal of Consciousness Studies", 12 (4-5), 18-37.

Schwartz, S. (2000). A Historical Loop of One Hundred Years: Similarities Between 19th Century and Contemporary Dream Research. „Dreaming”, 10, 55-66.

Schwitzgebel, E. (2002). Why Did We Think We Dreamed in Black and White? "Studies in History and Philosophy of Science Part A", 33 (4), 649-66o. http://doi. org/10.1016/Soo39-3681(02)ooo33-X.

Schwitzgebel, E. (2007). Do You Have Constant Tactile Experience of Your Feet in Your Shoes? Or Is Experience Limited to What's in Attention? "Journal of Consciousness Studies", 14(3), 5-35

Schwitzgebel, E. (2011). Perplexities of Consciousness. Cambridge, Mass: MIT Press.

Sikka, P., Valli, K., Virta, T. \& Revonsuo, A. (2014). I Know How You Felt Last Night, or do I? Self-and External Ratings of Emotions in REM Sleep Dreams. „Consciousness and Cognition",25, 51-66. http://doi.org/10.1016/j.concog.2014.01.011

Siclari, F., LaRocque, J.J., Bernardi, G., Postle, B.R. \& Tononi, G. (2014). The Neural Correlates of Consciousness in Sleep: A No-Task, Within-State Paradigm. The Neural Correlates of Consciousness in Sleep: A No-Task, Within-State Paradigm. bioRxiv, doi: http://dx.doi.org/10.1101/012443.

Solms, M. (1997). The Neuropsychology of Dreams: A Clinico-Anatomical Study. Mahwah, NJ: Erlbaum.

Strauch, I. \& Meier, B. (1996). In Search of Dreams: Results of Experimental Dream Research (M. Ebon, Trans.). New York: State University of New York Press.

Thompson, E. (2015). Dreamless Sleep, the Embodied Mind, and Consciousness In T.K. Metzinger \& J.M. Windt (Eds.), Open MIND. Frankfurt am Main: MIND Group. http://doi.org/10.15502/9783958570351.

Voss, U. \& Hobson, A. (2015). What is the State-of-the-Art on Lucid Dreaming? - Recent Advances and Questions for Future Research. In T. Metzinger \& 
J.M. Windt (Eds). Open MIND: 38(T). Frankfurt am Main: MIND Group. doi: $10.15502 / 9783958570306$.

Voss, U., Holzmann, R., Hobson, A., Paulus, W., Koppehele-Gossel, J., Klimke, A., et al. (2014). Induction of Self Awareness in Dreams Through Frontal Low Current Stimulation of Gamma Activity. „Nature Neuroscience”, 17 (6), 810-812. doi:10.1038/nn.3719.

Voss, U., Holzmann, R., Tuin, I. \& Hobson, J.A. (2009). Lucid Dreaming: A State of Consciousness with Features of Both Waking and Non-Lucid Dreaming. „Sleep”, 32 (9), 1191-1200.

Voss, U., Schermelleh-Engel, K., Windt, J.M., Frenzel, C. \& Hobson, J. A. (2013). Measuring Consciousness in Dreams: The Lucidity and Consciousness in Dreams Scale. "Consciousness and Cognition", 22, 8-21.

Windt, J.M. (2010). The Immersive Spatiotemporal Hallucination Model of Dreaming. "Phenomenology and the Cognitive Sciences", 9 (2), 295-316. http://doi. org/10.1007/s11097-010-9163-1.

Windt, J.M. (2013). Reporting Dream Experience: Why (not) to Be Skeptical About Dream Reports. „Frontiers in Human Neuroscience”, 7, 708. http://doi.org/10.3389/ fnhum.2013.00708.

Windt, J.M. (2015a). Dreaming: a Conceptual Framework for Philosophy of Mind and Empirical Research. Cambridge, Massachusetts ; London, England: MIT Press. Windt, J.M. (2015b), Dreams and Dreaming, ,The Stanford Encyclopedia of Philosophy” (Summer 2015 Edition), Edward N. Zalta (ed.), URL = <http://plato.stanford. edu/archives/sum2015/entries/dreams-dreaming/ > .

Windt, J.M. (in press). Just in Time-Dreamless Sleep Experience as Pure Subjective Temporality: A Commentary on Evan Thompson. In T.K. Metzinger \& J.M. Windt (Eds.), Open MIND. Frankfurt am Main: MIND Group.

Windt, J.M. \& Metzinger, T. (2007). The Philosophy of Dreaming and Self-Consciousness: What Happens to the Experiential Subject During the Dream State? In D. Barrett \& P. McNamara (Eds.), The New Science of Dreaming: Vol. 3. Cultural and theoretical perspectives (pp. 193-248). Westport: Praeger Perspectives.

Windt, J.M. \& Noreika, V. (2011). How to Integrate Dreaming Into a General Theory of Consciousness: A Critical Review of Existing Positions and Suggestions for Future Research. „Consciousness and Cognition”, 20 (4), 1091-1107.

Windt, J.M., Harkness, D.L. \& Lenggenhager, B. (2014). Tickle Me, IThink I Might Be Dreaming! Sensory Attenuation, Self-Other Distinction, and Predictive Processing in Lucid Dreams. „Frontiers in Human Neuroscience”, 8. http://doi.org/10.3389/ fnhum.2014.00717. 


\section{Abstract}

\section{Jennifer M. Windt}

MONASH UNIVERSITY

Dreaming, Consciousness \& the Self: A Philosophical Perspective

This article outlines the state of research on dreams and dreaming. Windt proposes a new conceptual framework to describe conscious experiences while dreaming. Building on methodological and theoretical achievements in the natural sciences as well as philosophy, she indicates new directions for the development of a philosophical theory of dreaming and related concepts of wakefulness, consciousness, and self-consciousness. Windt discusses the phenomenology of dreaming as well as the relations between the sleeping physical body and the dream self, including the experience of being a bodily self in dreams. This allows her to explore how standard wakefulness and altered states of consciousness, including bodily illusions and presence in virtual reality, relate to dreams and dreaming.

\section{Keywords}

dreaming, philosophy of dreaming, consciousness, phenomenology of wakefulness, lucid dreaming, self-consciousness 